\title{
DISASTER RULIUAE MATTERS
}

\section{JEROEN WARNER ${ }^{1}$ \\ KAREN ENGEL ${ }^{2}$}

After the Santa Catarina flood disaster in November 2005, which affected 1.500.000 people and killed 128, Brazil's central government promised to make disaster risk reduction a priority. At the moment however, it is fair to say that advances have been minimal. Still we can see a gradual shift in Brazil from disaster response to preparation, and from a deeply techno-centric approach to increasing acknowledgement of the important role social factors play when it comes to disasters. The present contribution argues for increasing prioritization of the social, recognition of culture, and promotion of a `disaster culture`(Wenger and Weller 1972, Wenger and Weller 1973, Wenger 1978, Moore 1964, Turner 1982) that promotes social resilience in the face of hazards (Engel and Engel 2012, Engel et al. 2014, Frerks et al. 2011).

Hazards may be natural, but disasters are not. Disasters arise as nature and society interact; they are mediated by human settlement and behaviour. An extreme force of nature hitting an area where nobody lives is not considered a disaster. As Wisner et al. (1994: 7) underline, "social systems operate to generate disasters by making people vulnerable." Take cities, where over $50 \%$ of the world's population now live, and which are often poorly designed when it comes to disaster risk reduction. Even if we wanted to, fast-moving (mega)cities cannot be expected to be resilient as in 'bouncing back` to the pre-disaster state after an event (Klein et al. 2003), and while ancient indigenous cultures and their architecture were often far more in tune with natural hazards than modern brick buildings (Hoffmann 2002), few urban dwellers would be prepared to forego their modern apartment for a Maya or Inca dwelling. Such realities put people at risk. Against this background it is important to realize that the current global trend for making vital infrastructure (roads, pipelines, schools, hospitals, town halls, green spaces) more resilient, reconsidering land-use planning, and rediscovering 'green buffers` that can reduce exposure to and impact of shocks, behaviour is more difficult to control and communities continue to inhabit and settle in inherently hazardous areas such as at the toes of volcanoes, on geological fault lines, in flood plains and along coasts.

To understand the logics underlying people's behaviour, social and cultural aspects are important and should not be overlooked. In fact, promoting a culture of resilience

1. Associate Professor of Disaster Studies, Social Sciences Group, Wageningen University, Hollandseweg 1, 6706 KN Wageningen. jeroenwarner@gmail.com; jeroen.warner@wur.nl (Corresponding author)

2. PhD candidate, Disaster Studies, Social Sciences Group, Wageningen University. Karen.engel@wur.nl 
can help prevent unnecessary victims and loss. For this, culture should not be seen as a hindrance, but as a pool of resources. This however is not conventional wisdom yet, as cultures are complex and often seen as unchangeable and encompassing important obstacles, such as taboos, intercultural communication issues and 'deviant' (non-conformist) behaviour. This is however a rather unhelpful perspective as it ignores important social and cultural assets that in fact might enable important prevention, mitigation or preparation functions. Additionally, understanding social realities and cultures requires engaging people. This too however, is often considered undesirable by responders who see disaster-affected people as apathetic, prone to panic and prone to looting (Oberije. s.d.) even though in the wake of a disaster, they rise to important challenges and bridge the gaps that formal responders cannot. Such ideas fly in the face of the empirical finding that in disaster situations people (even known criminals in the 'hood) display pro-social behaviour as neighbours, family, and existing and emergent networks rise to the occasion and save people and assets and supply basic services (Protevi 2011; Rodriguez et al. 2006). Most people, after all, are saved not by professional responders, but by family, friends, neighbours and passers-by - up to $99 \%$ in an earthquake event (Kirschenbaum 2004). In the hour of need and often all throughout recovery, people have to rely on their socialcultural networks; their social capital to overcome whatever disaster they lived. Even first responders will first look after their own.

Culture and cultural diversity, then are not just a challenge creating barriers, but are in fact reservoirs of available assets that people have available to them to prevent, mitigate, prepare for, cope with and adapt to disaster risks - cognitively and practically. People have a cultural assortment of knowledge, beliefs, values, norms, techniques and artefacts that help them engage with and manage their physical, natural and man-made, and social environment. In fact, cultures encompass problem-solving tools that over time have proven valuable to surviving in a particular environment (Schein 1999: 43; Engel et al. 2014).

Urban sub-communities such as illegal migrants, refugees, the homeless, travellers [gypsies], the handicapped, addicts, orthodox religious minorities and criminal networks, may be treated as social outcasts and hard to reach for planners, managers and responders but may well have strong survival networks among themselves. These networks and their associated cultures are however likely to be highly diverse. In line with the forthcoming Red Cross World Disaster Report 2014, we argue that response agencies will have to accept and engage with the different logics and rationalities that people rely on in the face of risk, and the different things they see as risk in their 'risk landscape'.

When challenged, people are `as good as the people they are surrounded with` (R. Giordano, pers. comm. 2014). The recognition that people are essentially social beings (Roling 2006) however flies in the face of the currently voguish liberal model of humans as rational individualists, expressed in disaster communication aimed at individuals and households in the West. This also qualifies the perspective on resilience, which is an analytical concept, but of late appears to have been promoted for ideological reasons (Frerks et al. 2011).

The second author of this paper found in Chile for instance, in her extensive field work (2013-14) that overcoming the major 2010 earthquake/tsunami disaster required 
first and foremost resources available throughout their social capital, i.e. through people's social networks. Also it became clear that those households recovering in isolation recover slower than those with increasing access to for instance social and political capital. Access to relevant resources, whether during or after a disaster are tied to people. Networks are, in turn, tied to cultures - professional, ideological, affective - that influence how people will operate in an emergency and the resources they eventually have access to. They inform how people (self)-organise and improvise in the face of disaster and more often than not, their actions do not conform to the disaster management plans. This is largely because such plans are elaborated beyond their reach and have subsequently no meaning to them. For Disaster Risk Reduction (DRR) plans, policies and practices to be effective they largely depend on the socio-cultural capacity of the affected communities. In areas where these dimensions are strong, they should be nourished and maintained, while in areas where they are not they should be promoted and strengthened. Ensuring adequate socio-cultural structures and acknowledging their importance will allow for enhanced community resilience. Resilience thus involves interaction and synergy between not just the human parts, but also between the human and the physical parts. 'Physical parts` refers to the often complex human artefacts that are also enclosed in cultures - storm surge barriers and earthquake-proof buildings.

For a culture of resilience to come about, then, it is of great importance that an adequate socio-cultural reservoir is available. What often complicates matters, however, is that different communities reach for their own sub-cultural reservoir and network and find it difficult to co-operate with external networks characterized by different sub-cultures. This obstacle often makes cooperation between formal and informal players in disaster situations difficult and has resulted in barely affordable inefficiencies. We therefore propose that when looking at specific localities it is important to identify and recognize the overall culture, but more importantly also the different sub-cultures that are relevant to effective DRR and their interaction. Engagement of likely and unlikely allies is key (Engel and Engel, 2012).

Once we accept that cultures matter, we can assess whether they make people (more) resilient. For instance, have people developed a false sense of security when they are told that certain governmental measures are taken and will keep them safe? In the Netherlands for instance, will the storm surge barriers keep everyone safe? Have the Dutch beaten nature into submission? Or can technique fail? Will more safety measures lead to more irresponsible behaviour? Will, for example, the highly sophisticated Dutch flood management scheme lead to more irresponsible behaviour like building in areas increasingly vulnerable to flooding? Yes, it already has, for lack of space to build and the faith we have in our water engineers, with a densely-populated, economically crucial province lying $2-5 \mathrm{~m}$ below sea level. Protection attracts investment and migration, putting more assets and people at risk - this 'safety paradox' is very much tied together with socio-cultural beliefs and artefacts. We needs to promote a realistic view, acknowledging that most locations are subject to recurring hazards, but that there is also scope for action. Letting people know there is danger without giving them an action perspective will promote fear or indifference. Risk awareness and action perspectives need to go hand in hand (Harries 2008). 
Especially with respect to rare events, awareness and routines are missing as they are generally not inscribed in and passed on as (folk)lore and practice. For instance, in 2010 Chilean coastal communities were aware of possible tsunamis and therefore knew to run up a hill when confronted with a major earthquake (beyond M7 on the Richter scale). This saved a lot of people. The more vulnerable however, were visitors coming in from more inland cities such as Santiago. Instead of running up hills, they did not react and remained close to the sea and were eventually unable to escape the tsunami. They were not part of the culture that had enabled the coastal communities to read and respond to their environment.

A disaster-resilient culture however cannot be engineered out of the blue; we will need to build on and strengthen what is there. While it is often suggested that cultures are static and fixed, they are not. Cultures are generated and regenerated by social innovation and learning processes that are triggered by people experiencing challenges as they interact with their physical, social and cultural environments. Relevant change however cannot be brought about without the engagement of relevant stakeholders, whether formal or informal, likely or unlikely, to reflect on our patterns of behaviour in disaster. We therefore argue for a genuinely inclusive reflective engagement and debate with all kinds of social groups on how to deal with disaster beyond the 'experts` and beyond top-down plans.

Next to the vital `hard infrastructure` then, soft infrastructure can play a crucial role in disaster risk reduction efforts--(sub)cultures, socio-cultural networks and their constantly evolving social practices. 'Soft infrastructure' is obviously less tangible and therefore more complex to grasp, appreciate and investigate than its more perceptible and concrete counterpart, 'hard infrastructure'. This is however no excuse to ignore it and subsequently preventing more community resilience from coming about.

\section{References}

Harries, T. 2011. Feeling secure or being secure? Why it can seem better not to protect yourself against a

natural hazard. Enfield, UK: Flood Hazard Research Centre. Health, Risk \& Society 10(5): 479-490. Online: http://eprints.kingston.ac.uk/18064/1/Accepted_for_Health_Risk_ and_Society_10_5.pdf?origin=publication_detail

Hoffmann, S.M. 2002. Culture and Catastrophe. The Anthropology of Disaster.

Kirschenbaum, 2004. Generic sources of disaster communities: a social network approach, International

Journal of Sociology and Social Policy, Vol. 24 Iss: 10/11, pp.94 - 129

Klein, R.J.T., Nicholls, R.J., and F. Thomalla (2003) 'Resilience to natural hazards: How useful is this concept?' Global Environmental Change Part B: Environmental Hazards, Volume $5(1-2): 35-45$. 
Oberijé, N. n.d. Civil response after disasters. The use of Civil engagement in disaster abatement. Nederlands Instituut voor Fysieke Veiligheid (NIFV). Online: http://www. infopuntveiligheid.nl/Infopuntdocumenten/Civil_Respons_after_Disasters[1].pd

Protevi, J. 2009. Katrina. In: B. Herzogenrath (ed.), Deleuze/Guattari E Ecology. Palgrave Macmillan. 363-381. Online http://philpapers.org/rec/PROK.

Roling, N. 2006. CONCEPTUAL AND METHODOLOGICAL DEVELOPMENTS IN INNOVATION. Keynote speech for Innovation Africa Symposium, November, Kampala, Uganda Kampala. Online: http://www.cgiar-ilac.org/files/Roeling_conceptual.pdf

Wenger DE (1978) Community response to disaster: functional and structural alterations. In: Quarantelli EL (ed) Disasters: theory and research. Sage Publications, London

Wenger DE, Weller JM (1972) Some observations on the concept of disaster subculture. Disaster Research Center Working Paper \#48. Disaster Resarch Center, Ohio State University, Columbus, Ohio.

Wenger DE, Weller JM (1973) Disaster subcultures: the cultural residue of community disasters, Disaster.

Research Center Preliminary Paper \#9. Disaster Research Center, Ohio State University, Columbus.

Turner RH (1982) Disaster subcultures in earthquake country: between earthquakes in southern California, paper presented at the Third International Conference of the Earthquake Hazard Mitigation Program held on 29 June-2 July 1981 in Yugoslavia.

Moore HE (1964) And the winds blew. Austing, Hogg Foundation for Mental Health, Univeristy of Texas, Texas.

Marín A, Gelcich S, Araya G, Olea G, Espíndola M, Castilla JC (2010) The 2010 tsunami in Chile: devastation and survival of coastal small-scale fishing communities. Mar Policy: 1381-1384.

Engel KE, Engel PGH (2012) Building resilient communities: where disaster management and facilitating innovation meet. In: Wals AEJ (ed) Learning for sustainability in times of accelerating change. Wageningen Academic Publishers, Wageningen, pp 133-147.

Engel K, Trainor JE (2010) Floods and disaster management in the Netherlands: God created the world, but the Dutch created the Netherlands. In McEntire D (ed.) Comparative emergency management. FEMA in Higher Education Program. http:// training.fema.gov/EMIWeb/edu/CompEmMgmtBookProject.asp Accessed 14-10-2014.

Frerks G, Warner J, and Weijs B 2011 The politics of vulnerability and resilience. Ambiente y Sociedade 14(2): 105-122.

Rodriguez H, Trainor J, and Quarantelli EL (2006) Rising to the Challenges of a Catastrophe: The Emergent and Prosocial Behavior following Hurricane Katrina. Annals of the American Academy of Political and Social Science, Vol. 604, Shelter from the Storm: Repairing the National Emergency Management System after Hurricane Katrina (Mar., 2006), pp. 82-101. 
Submitted on: 03/08/2014.

Accepted on: 18/10/2014.

http://dx.doi.org/10.1590/1809-4422ASOCEx002V1742014 


\title{
DISFSTER CLULIURE MATTERS
}

\author{
JEROEN WARNER \\ KAREN ENGEL
}

\begin{abstract}
The present contribution argues for increasing prioritization of the social, recognition of culture, and promotion of a disaster culture that promotes social resilience in the face of hazards. The current global trend has been to make vital infrastructure more resilient. But behavior is more difficult to control and communities continue to inhabit and settle in inherently hazardous areas. This short text shows how relevant it is to understand the logics underlying people's behavior, social and cultural aspects. In fact, promoting a culture of resilience can help prevent unnecessary victims and loss. For this, culture should not be seen as a hindrance, but as a pool of resources.
\end{abstract}

Key words: disaster culture, risk and hazards, behavior, resilience.

Resumo: Esta contribuição enfatiza a necessidade de priorizar o reconhecimento social de uma cultura de desastres que promova a resiliência social face aos perigos.A tendência global tem sido de tornar a infraestrutura vital mais resiliente. Porem o comportamento é muito mais difícil de controlar e as comunidades pobres continuam vivendo em áreas inerentemente sujeitas a perigos e desastres. Este curto texto mostra a importância de entender a lógica que permeia o comportamento social e cultural das pessoas. A promoção de uma cultura de resiliência pode contribuir para prevenir vítimas e perdas desnecessárias. Para tanto, a cultura não deveria ser vista como um impedimento, mas como um conjunto de recursos.

Palauras-Chave: cultura de desastre, riscos e perigos, comportamento, resiliência.

Resumen: Esta contribución destaca la necesidad de priorizar el reconocimiento social deuna cultura de desastres que promueva la resiliencia social frente a los peligros.La tendencia global ha sido de desarrollar una infraestructura más resiliente. Entretanto el comportamiento es mucho más difícil de controlar y las comunidades pobres continúan viviendo en áreas permanentemente sujetas a peligros y desastres. Este breve texto muestra la importancia de entender la lógica que subyace el comportamiento social y cultural de las personas. La promoción de una cultura de resiliencia puede contribuir para prevenir victimas y pérdidas desnecesariamente. Para tanto, la cultura no debería ser vista como un impedimento, pero si como un conjunto de recursos. 
Palabras Clave: cultura de desastres, riesgos y peligros, el comportamiento, la capacidad de recuperación. 